\title{
Molar-incisor enamel hypomineralization cross-sectional prevalence evaluation in oral-breathing allergic children
}

\author{
- Silvana Frascino Department of Otorhinolaryngology and Head and Neck Surgery, Division of Pediatric Otolaryngology, \\ Federal University of São Paulo, São Paulo, SP, Brazil • Alexandre Frascino Pediatric Departament, School of Medicine, \\ University of São Paulo, São Paulo, SP, Brazil • Karla Mayra Rezende Department of Pediatric Dentistry, School of Dentistry, \\ University of São Paulo, São Paulo, SP, Brazil • Jose Carlos Imparato Head of Department of Pediatric Dentistry, School of \\ Dentistry, University of São Paulo, São Paulo, SP, Brazil • Shirley Pignatari Department of Otorhinolaryngology and Head and \\ Neck Surgery, Division of Pediatric Otolaryngology, Federal University of São Paulo, São Paulo, SP, Brazil
}

\begin{abstract}
Objective: Molar-incisor hypomineralization (MIH) is a highly prevalent dental development disturbance caused by disrupted ameloblast maturation. This condition affects up to $44 \%$ of children around the world and several systemic conditions have been associated with MIH, including Mouth-Breathing. It is important to show that MIH has multifactorial etiology and is associated with allergic mouth-breathing children. Methods: To evaluate MIH prevalence in MBCS children with positive and negative allergic response to the skin prick test, a cross-sectional quantitative and qualitative comparative assessment was conducted in 23 mouth-breathing children and 25 sex/age-matched siblings. Enamel defects were classified by the modified rate of FDI Development Defects of Enamel. Statistical Student's t tests were applied to verify the relevance of the data. Results: MIH prevalence showed significant statistical differences in the comparison between molars, independently of individual age $(\mathrm{p}=0.01513474)$. MBCS children under 5 years old had higher statistical prevalence of MIH ( $\mathrm{p}=0.00594)$. MBCS children with positive skin reactions to the prick test had higher prevalence of MIH (p $=0,023)$. MBCS children had statistically significant higher prevalence of demarcated opacity $(\mathrm{p}=0.00012)$. Conclusions: Finally, MBCS children with positive skin reactions to the prick test had higher prevalence of MIH ( $p=0,023$ ), indicating that mouth-breathing allergy-responsive children had higher MIH prevalence. Our results corroborate our previous hypothesis that MBCS children have increased MIH prevalence in comparison to their siblings, with statistical significance (p = o.01513474). Further investigations with larger samples may enhance and confirm the accuracy of our results.
\end{abstract}

DESCRIPTORS | Hypomineralization; Enamel Hypoplasia; Molar-incisor Hypomineralization; Pediatric Dentistry; Oral Breathing; Allergy.

RESUMO | Avaliação da prevalência transversal da hipomineralização incisivo-molar do esmalte em crianças alérgicas com respiração oral • Objetivo: Hipomineralização incisivo-molar (HIM) é um distúrbio de desenvolvimento dentário altamente prevalente devido à maturação interrompida do ameloblasto. Esta condição afeta até $44 \%$ das crianças ao redor do mundo e várias condições sistêmicas têm sido associadas à HIM, incluindo a respiração oral. E importante mostrar que HIM tem etiologia multifatorial e está associada com crianças alérgicas com respiração bucal. Métodos: Para avaliar a prevalência da HIM em crianças com SRBI com resposta alérgica positiva e negativa para testes de escarificação, uma avaliação transversal quantitativa e qualitativa foi realizada em 23 crianças com respiração oral e 25 irmãos com idade/sexo correspondentes. Defeitos de esmalte foram classificados de acordo com o índice de defeitos de esmalte da FDI. Teste t de Student foi aplicado para verificar a relevância dos dados. Resultados: A prevalência de HIM mostrou diferenças estatísticas significativas na comparação entre molares, independentemente de idade individual ( $\mathrm{p}=0,01513474)$. Crianças com SRBI menores de 5 anos apresentaram maior prevalência estatística de HIM ( $\mathrm{p}=$ 0,00594). Crianças com SRBI que obtiveram reações positivas para os testes de escarificação apresentaram maior prevalência de HIM ( $\mathrm{p}=0,023)$. Crianças com SRBI apresentaram maior prevalência estatística de opacidade demarcada $(\mathrm{p}=0,00012)$. Conclusões: Crianças com SRBI que obtiveram reações positivas para os testes de escarificação apresentaram maior prevalência de HIM $(\mathrm{p}=0,023)$, indicando que crianças alérgicas com respiração oral tiveram maior prevalência de HIM. Nossos resultados corroboram nossa hipótese anterior que crianças com SRBI demonstram maior prevalência de HIM em comparação com seus irmãos, com significância estatística ( $\mathrm{p}=0$,01513474). Investigações com amostras populacionais maiores podem reforçar e confirmar a exatidão dos nossos resultados

DESCRITORES | Hipomineralização; Hipoplasia de esmalte; Hipomineralização incisivo-molar; Odontopediatria; Respiração oral; Alergia

CORRESPONDING AUTHOR | - Alexandre Frascino Pediatric Departament, School of Medicine, University of São Paulo - Av. Dr. Enéas de Carvalho Aguiar, 647, Pinheiros São Paulo, SP, Brazil•05403000 E-mail: alexandre.frascino@usp.br

- Received July 10, 2017 • Accepted Aug 23, 2017

- Dol http://dx.doi.org/10.11606/issn.2357-8041.clrd.2017..134317 


\section{INTRODUCTION}

\section{Background}

Molar-Incisor hypomineralization (MIH) is a set of qualitative enamel defects affecting one to four molar teeth, with or without analogous incisors' affection ${ }^{1-3}$ resulting from disrupted ameloblasts' maturation leading to qualitative enamel defects. ${ }^{4} \mathrm{MIH}$ prevalence has been reported to range from 2.9 to $44 \%$ around the world ${ }^{5-7}$ presenting itself clinically as asymmetric white/opaque, yellow or brown discoloration with clear distinction from healthy enamel ${ }^{8,9}$ often affecting occlusal and buccal surface. ${ }^{1,5,9-12}$ Increased prevalence of dental caries has been associated with MIH due the presence of sites for the adhesion and colonization of aciduric bacteria..$^{9,10,13,14}$

Several systemic conditions have been associated ${ }^{7}$, including prenatal complications, pre-term birth, low birth-weight, nutritional deficiencies, celiac disease, sickle cell anemia, fever, metabolic disorders of calcium and phosphate, renal insufficiency, stem-cell hematopoietic transplantation, chemical and/or radiotherapy, neurological disparities, hypoparathyroidism and head trauma. ${ }^{6,15,16}$ The association between respiratory diseases and MIH has been extensively investigated during the last decade. ${ }^{11,17}$ Several authors have found a positive correlation between allergic respiratory diseases and the severity of MIH. ${ }^{1,5,12,16,17}$

Mouth-breathing children syndrome (MBCS) is a childhood breathing pattern disturbance characterized by mixed or oral air inhalation. MBCS is associated with disorders of the speech and is generally combined with facial deformities, with the potential to progress to cardiorespiratory, endocrine diseases and sleep disturbances that can impair their mental and physical development. ${ }^{18-22}$ Furthermore, this syndrome has been related to genetic factors, unhealthy oral habits and nasal obstructions of varying degrees of severity and duration and has also been associated with pediatric allergy-related otorhinolaryngology complaints..$^{2,15,23}$
Also, MBCS patients are more prone to having caries, tooth erosion, malocclusion, improper dental and craniofacial growth and development, bruxism and increased dental trauma incidence. MBCS effects on MIH have been previously investigated, however, there are no investigations of $\mathrm{MIH}$ prevalence among MBCS children with or without positive reaction to the skin prick test.

\section{Objective}

The goal of this study is to investigate through a cross-sectional case-control the prevalence of MIH among allergic mouth-breathing children.

\section{METHODS}

\section{Study design}

A cross-sectional case-control clinical comparison of MIH prevalence in MBCS and nonMCBS children.

\section{Setting}

Cases and age and sex-matched controls were selected at the Mouth Breathing Center of the Federal University of São Paulo's Medicine School, from December 2001 to December 2011.

All the ethical principles expressed in the World Medical Association Declaration of Helsinki were followed in this study and all the parents of the children, after they received oral and written explanations of the experimental protocol and the study's aims, gave their written informed consent. The approval for this study was obtained from the ethical committee of the Federal University of São Paulo Medicine School.

\section{Sample selection}

\section{Study group}

The study group was composed by 23 mouthbreathing children, between 5 and 17 years old, 
recruited from the Federal University of São Paulo's Medicine School. The parents gave their respective signed agreement for voluntary participation. Each child had their breathing pattern diagnostic after a thorough physical exam performed by a trained othorrinolaringologist.

\section{Control group}

The control group was composed by 25 children similarly distributed by age and sex. Medical history was assessed, and a physical exam was performed to confirm their nasal breathing pattern.

\section{Prick test}

To determine the childrens' allergic predisposition to specific allergenic air particles, skin prick tests were undertaken in both groups. Dermic responses were evaluated by a trained allergist.

\section{DENTAL EXAMINATIONS}

\section{Molar-incisor hypoplasia evaluations}

The quantitative and qualitative assessment of MIH prevalence was performed through a careful clinical exam conducted by a pediatric dentist who evaluated all four first molars, central and lateral incisors. The teeth were evaluated under an artificial lighting reflector immediately after the cleaning and air drying of the dental elements to classify enamel defects according to the modified Development Defects of Enamel index ${ }^{20,24-28}$ according to FDI. ${ }^{29,30}$

\section{Statistical Analyses}

Descriptive statistical analysis (means, standard deviations, percentages) were calculated using Excel (Microsoft for Mac 15.24). The data comparison of statistical associations (p-values) were assessed using Student's $t$-test to verify the statistical significance of MIH prevalence among mouthbreathing and nasal-breathing children ( $\mathrm{p}<0.05)$. To verify the correlation between positive skin reaction to the prick test and MIH prevalence, Student's $t$-test was employed as well $(\mathrm{p}<0.05)$. Exact Fisher's test was used to verify the type of enamel defect and breathing pattern $(\mathrm{p}<0.05)$.

\section{RESULTS}

The case group was composed by 23 mouthbreathing children and 25 nasal-breathing children with mean age of 14.2 years old (Table 1 ).

Enamel hypomineralization in molar teeth was significantly more prevalent in MBCS children, independently of individual age $(\mathrm{p}=0.01513474)$ (Figure 2). Also, there was significant statistical difference in MIH prevalence between oral-breathing and nasal-breathing children when only those below 5 years old at the time of the exam were compared ( $\mathrm{p}=0.0054904)$ (Table 2).

There was no statistical significance in the prevalence of MIH and positive skin reaction to the prick test, though borderline value was seen in the comparison between molars (0.0691). However, MBCS children with positive skin reactions to the prick test had higher prevalence of MIH $(\mathrm{p}=0,023)$, indicating that mouth-breathing allergy-responsive children had higher MIH prevalence.

The type of enamel defect and breathing pattern was also evaluated through Fisher's Exact Test. Mouth-breathing children showed a statistically significant higher prevalence of demarcated opacity ( $\mathrm{p}=0.00012$ ), though all other MIH-pre-determined enamel defects were considered outliers since there was not enough volume of data for statistical analyses.

\section{DISCUSSION}

MIH is the qualitative development of enamel defect found in $19.8 \%$ of Brazilian children, with strong evidence indicating positive correlation between MIH and the prevalence of dental caries. ${ }^{3,6,7,10,14,29}$ Despite the high prevalence, there is no conclusive data about MIH's etiology, though several systemic factors of early childhood are known 
to impair the activity of ameloblasts through enamel production and mineralization. In all possibilities, the relevance of each event is difficult to establish as many of them can happen more than once during early childhood..$^{12,16,17,31}$

In this study, the prevalence of MIH in MBCS children, with or without positive skin reaction to allergic prick test, was investigated following the mDDE classification. This index has been employed previously with consistent and comparable results, ${ }^{13,32}$ notwithstanding the known low-specificity issues of this classification. To assure acceptable variability in this investigation, all the patients and control volunteers were evaluated by a single calibrated pediatric dentist, minimizing variations caused by different viewers. A newer method to classify and compare MIH was proposed by EAPD in $2003^{8}$, aiming to provide a more precise classification which also worked as a reproducible method; it was not considered in the present study due to the dissemination of a higher mDDE index. , $, 6,7,13,33^{-}$

Mouth-breathing caused by the obstruction of the upper airways in early childhood affects several aspects of the children's growth, including disturbances in orofacial development, and several other associated issues with several long-term effects and quality of life impairment. ${ }^{18,34-36}$ Also, MBCS children are at a higher risk of developing allergic responses, though the exact mechanisms are not fully elucidated. The relationship between mouthbreathing patterns and increased prevalence of dental caries has already been established. However, despite the clinical observance of augmented presence of enamel hypoplasia, there have been no previous investigations of MIH in MBCS children.9,10,37 Our results corroborate our previous hypothesis that the latter exhibit increased MIH prevalence in comparison to their siblings, with statistical significance $(\mathrm{p}=0.01513474)$.

The negative impacts of mouth-breathing in early childhood have been extensively investigated.
Several authors evidenced impairments in speech, snoring, chewing, and abnormal craniofacial growth in MBCS children. ${ }^{18-20,22,25,27,38}$ Our results confirm the extensive list of local and systemic impairments associated with improper breathing pattern. ${ }^{27,39,40}$ Age was also described as a negative modifying factor of MIH prevalence, being statistically significant ( $\mathrm{p}=0.00594)$.

Although there were statistically significant results in the type of enamel hypoplasia and breathing pattern, there are several restraints regarding these results, since there were a high number of outliers and grouped MIH. Also, previously published data cannot be compared with these results since different MIH evaluation methods and cases have been used. Among the limitations of the present work, the authors believe that further investigations with this group of patients should be carried out, mostly due to the power of the evaluated sample being too weak to reveal consistent results.

\section{CONCLUSIONS}

Molar-incisor hypoplasia seems to be more prevalent in mouth-breathing children, although no statistical significance could be established between $\mathrm{MIH}$ and allergic prick-test responsive MBCS children. Larger population studies may enhance and confirm the accuracy of our results.

\section{REFERENCES}

1. Willmott NS, Bryan RAE, Duggal MS. Molar-incisor-hypomineralisation: a literature review. Eur Arch Paediatr Dent. 2008;9(4):172-9.

2. Souza JF, Jeremias F, Costa-Silva CM, Santos-Pinto L, Zuanon AC, Cordeiro RC. Aetiology of Molar-incisor hypomineralisation (MIH) in Brazilian children. Eur Arch Paediatr Dent. 2013;14(4):233-8.

3. Souza JF, Costa-Silva CM, Jeremias F, Santos-Pinto L, Zuanon AC, Cordeiro RC. Molar incisor hypomineralisation: possible aetiological factors in children from urban and rural areas. Eur Arch Paediatr Dent. 2012;13(4):164-70. 
4. Farah RA, Monk BC, Swain MV, Drummond BK. Protein content of molar-incisor hypomineralisation enamel. J Dent. 2010;38(7):591-6.

5. Lima MDM, Andrade MJ, Dantas-Neta NB, Andrade NS, Teixeira RJ, Moura MS, et al. Epidemiologic study of Molar-Incisor Hypomineralization in schoolchildren in north-eastern Brazil. Pediatr Dent. 2015;37(7):513-9.

6. Costa-Silva CM, Jeremias F, Souza JF, Cordeiro RC, Santos-Pinto L, Zuanon AC. Molar incisor hypomineralization: prevalence, severity and clinical consequences in Brazilian children. Int J Paediatr Dent. 2010;20(6):426-34.

7. Condò R, Perugia C, Maturo P, Docimo R. MIH: epidemiologic clinic study in paediatric patient. Oral Implantol (Rome). 2012;5(2-3):58-69.

8. Lygidakis NA, Wong F, Jälevik B, Vierrou AM, Alaluusua S, Espelid I. Best clinical practice guidance for clinicians dealing with children presenting with Molar-Incisor-Hypomineralisation (MIH): an EAPD policy document. Eur Arch Paediatr Dent. 2010;11(2):75-81.

9. Americano GC, Jacobsen PE, Soviero VM, Haubek D. A systematic review on the association between Molar Incisor Hypomineralization and dental caries. Int J Paediatric Dent. 2017;27(1):11-21.

10. Jeremias F, Souza JF, Silva CM, Cordeiro RC, Zuanon AC, Santos-Pinto L. Dental caries experience and Molar-Incisor Hypomineralization. Acta Odontol Scand. 2013;71(3-4):8706.

11. Sönmez H, Yıldırım G, Bezgin T. Putative factors associated with molar incisor hypomineralisation: an epidemiological study. Eur Arch Paediatr Dent. 2013;14(6):375-80.

12. Kühnisch J, Mach D, Thiering E, Brockow I, Hoffmann U, Neumann C, et al. Respiratory diseases are associated with molar-incisor hypomineralizations. Swiss Dent J. 2014;124(3):286-93.

13. Costa-Silva CM, Ambrosano GM, Jeremias F, Souza JF, Mialhe FL. Increase in severity of molar-incisor hypomineralization and its relationship with the colour of enamel opacity: a prospective cohort study. Int J Paediatr Dent. 2011;21(5):333-41.

14. Heitmüller D, Thiering E, Hoffmann U, Heinrich J, Manton D, Kühnisch J, et al. Is there a positive relationship between molar incisor hypomineralisations and the presence of dental caries? Int J Paediatr Dent. 2013;23(2):116-24.

15. Lygidakis NA, Dimou G, Briseniou E. Molar-incisor-hypomineralisation (MIH). Retrospective clinical study in Greek children. I. Prevalence and defect characteristics. Eur Arch Paediatr Dent. 2008;9(4):200-6.

16. Lygidakis NA, Dimou G, Marinou D. Molar-incisor-hypomineralisation (MIH). A retrospective clinical study in Greek children. II. Possible medical aetiological factors. Eur Arch Paediatr Dent. 2008;9(4):207-17.

17. Silva MJ, Scurrah KJ, Craig JM, Manton DJ, Kilpatrick N. Etiology of molar incisor hypomineralization: a systematic review. Community Dent Oral Epidemiol. 2016;44(4):342-53

18. Souki BQ, Lopes PB, Pereira TB, Franco LP, Becker HM, Oliveira DD. Mouth breathing children and cephalometric pattern: does the stage of dental development matter? Int $J$ Pediatr Otorhinolaryngol. 2012;76(6):837-41.

19. Pacheco MC, Fiorott BS, Finck NS, Araújo MT. Craniofacial changes and symptoms of sleep-disordered breathing in healthy children. Dental Press J Orthod. 2015;20(3):80-7.

20. Hitos SF, Arakaki R, Solé D, Weckx LL. Oral breathing and speech disorders in children. J Pediatr (Rio J). 2013;89(4):361-5.

21. Chung Leng Muñoz I, Beltri Orta P. Comparison of cephalometric patterns in mouth breathing and nose breathing children. Int J Pediatr Otorhinolaryngol. 2014;78(7):1167-72.

22. Bolzan GP, Souza JA, Boton LM, Silva AMT, Corrêa ECR. Facial type and head posture of nasal and mouth-breathing children. J Soc Bras Fonoaudiol. 2011;23(4):315-20.

23. Mishra A, Pandey RK. Molar Incisor Hypomineralization: an epidemiological study with prevalence and etiological factors in indian pediatric population. Int J Clin Pediatr Dent. 2016;9(2):167-71.

24. Bateson TF, Schwartz J. Children's response to air pollutants. J Toxicol Environ Health A. 2008;71(3):238-43.

25. Bresolin D, Shapiro PA, Shapiro GG, Chapko MK, Dassel S. Mouth breathing in allergic children: its relationship to dentofacial development. Am J Orthod. 1983;83(4):334-40.

26. Chirakalwasan N, Ruxrungtham K. The linkage of allergic rhinitis and obstructive sleep apnea. Asian Pac J Allergy Immunol. 2014;32(4):276-86.

27. Ng DK, Chan CH, Hwang GY, Chow PY, Kwok KL. A review of the roles of allergic rhinitis in childhood obstructive sleep apnea syndrome. Allergy Asthma Proc. 2006;27(3):240-2.

28. Thomas MS, Parolia A, Kundabala M, Vikram M. Asthma and oral health: a review. Aust Dent J. 2010;55(2):128-33.

29. Tourino LF, Corrêa-Faria P, Ferreira RC, Bendo CB, Zarzar PM, Vale MP. Association between Molar Incisor Hypomineralization in schoolchildren and both prenatal and 
postnatal factors: a population-based study. PLoS One. 2016;11(6):e0156332.

30. A review of the developmental defects of enamel index (DDE Index). Commission on Oral Health, Research \& Epidemiology. Report of an FDI Working Group. Int Dent J. 1992;42(6):411-26.

31. Garg N, Jain AK, Saha S, Singh J. Essentiality of early diagnosis of molar incisor hypomineralization in children and review of its clinical presentation, etiology and management. Int J Clin Pediatr Dent. 2012;5(3):190-6.

32. Seow WK, Leishman SJ, Palmer JE, Walsh LJ, Pukallus M, Barnett AG. A longitudinal observational study of developmental defects of enamel from birth to 6 years of age. JDR Clin Trans Res. 2016;1(3):285-91.

33. Weerheijm KL, Duggal M, Mejàre I, Papagiannoulis L, Koch G, Martens LC, et al. Judgement criteria for molar incisor hypomineralisation (MIH) in epidemiologic studies: a summary of the European meeting on MIH held in Athens, 2003. Eur J Paediatr Dent. 2003;4(3):110-3.

34. Jefferson Y. Mouth breathing: adverse effects on facial growth, health, academics, and behavior. Gen Dent. 2010;58(1):18-25.
35. Harari D, Redlich M, Miri S, Hamud T, Gross M. The effect of mouth breathing versus nasal breathing on dentofacial and craniofacial development in orthodontic patients. Laryngoscope. 2010;120(10):2089-93.

36. Flutter J. The negative effect of mouth breathing on the body and development of the child. Int J Orthod Milwaukee. 2006;17(2):31-7.

37. Nascimento E Filho, Mayer MP, Pontes P, Pignatari AC, Weckx LL. Caries prevalence, levels of mutans streptococci, and gingival and plaque indices in 3.0- to 5.0-year-old mouth breathing children. Caries Res. 2004;38(6):572-5.

38. Poachanukoon O, Kitcharoensakkul M. Snoring and sleep problems in children with and without allergic rhinitis: a case control study. J Med Assoc Thai. 2015;98(Suppl 2):S138-44.

39. Yamaguchi H, Tada S, Nakanishi Y, Kawaminami S, Shin T, Tabata R, et al. Association between mouth breathing and atopic dermatitis in japanese children 2-6 years old: a population-based cross-sectional study. PLoS One. 2015;10(4):e0125916.

40. Endre L. Physical exercise and bronchial asthma. Orv Hetil. 2016;157(26):1019-27. 